\title{
M. DELAFOSSE'S ACCOUNT OF THE FULANI.
}

Ownng to the courtesy of the Editor of the African Mail, I was permitted during the last two years to publish a somewhat lengthy and discursive series of notes on the Fulani. ${ }^{1}$

Since those notes were written there has appeared from the pen of M. Delafosse an account of the Fulani and their origin, which must be regarded as of considerable authority, based, as it is, on the data accumulated by the French West African Colonial Service during a number of years.

It would be such a boon to all students of West African peoples if authorities could agree about certain basic facts regarding the Fulani, that I venture to raise some points in connection with M. Delafosse's theory in the hope that someone of wider erudition may be induced to join in its discussion.

In Frief, M. Delafosse's theory is as follows :-

He assumes that certain peoples, whom he calls JudæoSyrian, migrated from the region of Syria to Cyrenaica at a very remote period. They spoke an Egypto-Aramaean tongue, and their religion was an early form of Judaism.

Some of these Jews migrated from Cyrenaica to the Air region, and then to the Upper Niger, about 200 A.D. : others found a similar objective by way of Tuat.

Arrived in the region of the ancient Ghana, they found the country occupied by Soninke (Wakore), but eventually became predominant, and ruled as the "White Race of Ghana" in this region from the fourth to the eighth centuries.

During the eighth century they were for the most part

1 Africar Mail. December 29, 1911 -August 8, 1913.

- Delafosse, Haut Semegal at Niger. Paris, 1912.3 volumes. 
expelled from the Ghana region, and took refuge among the Tukrur (Tucolor), whose language they adopted, and from this time became Fulani.

The writer is in entire agreement with $M$. Delafosse in attributing the genesis of the Fulani as a people to a comparatively recent period, and in holding that an important element in their composition was either Jewish or of Jewish affinity.

But the remainder of the theory that $M$. Delafosse develops from these central facts would appear far less certain.

M. Delafosse's whole supposition of the migration via Air is based-

(a) On a Fulani legend which does not mention "Air" by name.

(b) On the mere statement in a Roman author that a Roman General (Julius Maternus) went South to a place Agisymba, which M. V. de St. Martin, in all probability correctly, identified with Air.

The Fulani legend, in fact, speaks of a migration via Bornu by which $M$. Delafosse, perhaps under the impression that Air was at this period tributary to Bornu, or rather Kanem, considers Air is meant.

The supposition is, however, quite without foundation, for (a) there is no evidence that the Kanem dominion was ever called Bornu, and though sometimes raided, Air has never really been subject to Bornu; (b) the whole Air region was in 891 A.D. still controlled by the Lamta Tuareg, ${ }^{1}$ and it was certainly subsequent to this date that the Kanembu and Kanuri of history gained any footing west of the meridian of Kauwar.

Again, the evidence in general put forward by $M$. Delafosse for both these supposed s,ecific migrations, when carefully weighed, simply amounts to this, that, as is well known, Judaism was a strong force in North Africa from a very early period. When we read the history of the Berguaba, Gomere, and other of the older Berber tribes in the West, who must have been in the closest touch with the Ghana

1 Vid. Yacubi ed Juynboll et de Goeje, p. 44 
region, and see that they practically adopted a Jewish cult, there is no need to account for Judaistic practices on the Niger from other sources.

Referring to the language question, it is difficult, having regard to parallel cases elsewhere, to explain why, if these Judæo-Syrians ruled Mande-speaking Soninke for four centuries, the former did not either teach the latter Aramaean, or themselves become Mande-speaking.

If it was simply from their historic contact with the Tucolor that the Fulani derived their language, we should hardly expect the glimpses which we get from El Bekri (eleventh century), of the Honeihim or El Famam-whom M. Delafosse admits to be Fulani-to indicate, as they do, nomadic and pariah communities. The Tucolor in M. Delafosse's hypothesis must have been a settled people with probably other peoples speaking cognate tongues in their neighbourhood. When an immigrating people loses its own language, and adopts the language of the indigenes, that process hardly takes place without free intermarriage.

Endogamy and extreme exclusiveness were, on the contrary, the characteristic traits of the Fulani, as opposed to the Tucolor or Toronke.

Though it is true that "Soninke" were subjects of the rulers of Ghana, and that they were in later times Mandespeaking, the predominance of the Mande influence and language only began about the time that the white dynasty of Ghana ceased to rule, i.e., with the conquest of Ghana by the Mande King of Wagadu, a region lying far to the South.

The war between languages is as constant as the war between tribes. Assuming that Fulani is really Tukruri, that language can hardly, as may be seen from the researches of Professor Meinhof and others, have been an "isolated" or "unique product." Language cannot be strictly divided into negro and non-negro, and, in fact, the weight of modern philological opinion goes to show that at one period a language which may be regarded as the parent of Fulanchi, in common with other languages now spoken as far apart as South Africa and East Africa, was very widely spoken over North Africa. 
Though the Wakore and Soninke, when we first knew them, spoke a Mande language, it does not follow that they always did so.

Further, if conjecture may be admitted, it is a very probable conjecture that the Wakore were themselves in origin invading Hamites of a type like the Teda or East African Hamites.

It will be observed that through the Sudan region are found a regular class of tribal names which point conclusively to a common ethnic and linguistic connection between the Hamites or semi-Hamites of West, East and South Africatribal names, moreover, which are certainly anterior to present or recorded tribal groupings.

The most obvious of these are forms compounded with "San" or "Sa," and forms having the prefix or affix "Wa" or "Awa."

While at the present time "San" is known as a Hottentot word for "people," and the meaning of "Wa" is seen in the names Wa-huma, \&c., of East Africa, it does not seem to have been pointed out that these two common nouns are equally present in the names:-

$\begin{array}{ll}\text { Wa-kore } & \text { (Wa'n'gara). } \\ \text { San-\{ } \begin{array}{c}\text { we } \\ \text { ghai }\end{array} & \text { (Songhay). } \\ \text { San-inke } & \text { (Soninke) } \\ \text { San-haja } & \text { (= wa-kore). } \\ \text { Wa-n-dala } & \text { (Rock people of Kanem). } \\ \text { Haus-awa } & \text { (for Habesh-awa). } \\ \text { Gobir-awa } & \\ \text { Sa(n)-lampta } & \text { (place name). } \\ \text { San-tolo } & \text { (place name). } \\ \text { San-fotir } & \text { (Fulani tribal name). } \\ \text { Wangar-awa } & \text { (Hausa name for Wakore). }\end{array}$

When an affix or suffix meaning "people" is found added on to a word which itself means "people," the history of such a name is evident.

In San-inke (or Soninke)-the affix "inke" is a Mande 
affix meaning people-and "san" is presumably the name by which this group either called themselves or were called by peoples other than the Mande themselves.

There is therefore every reason to believe that the Soninke were not originally Mande-speaking, but that on the contrary it was only after the Wagadu conquest of Ghana in 790 A.D. that the Mande. language ousted a pre-existing tongue, allied on the one hand to the Berber languages of North-west Africa, and perhaps on the other to the Hottentot languages of South Africa.

If in common with M. Delafosse we hold that some elements in the population of Ghana were proto-Fulani, surely it is easier to suppose that the rather elusive Wa-kore changed their language to Mande and, in fact, became Mande, than that the Fulani, after retaining a foreign idiom (Aramaean) for four hundred years, could exchange it for "Tukruri" (Tukolor) without altering their way of living, and, indeed, becoming indistinguishable from the "Tucolor."

Tukrur and Baghena are side by side. There is every reason to think that the early languages of Tukrur would be similar to those of Baghena and countries still further north.

The rise of the Mande (Mandingo) power, on the one hand, and the Tuareg on the other, are quite sufficient to account for the subsequent limitation of the Tukrur language (Fulanchi) to-

(a) The Fulani-nomad pastors of Baghena;

(b) The populations of Tukrur (i.e., Jenue-Silla, \&c.).

The data put forward by M. Delafosse to support his hypothesis, square equally well with ours.

But if, on the other hand, as M. Delafosse thinks, the Fulani acquired their language in Tukrur after having lived for four hundred years as a ruling caste in Baghena, it is hard to understand why the Judæo-Syrian tribes, which, previous to the assumed settlement in Baghena, stopped at Masina, as well as the Judæo-Syrians who remained behind in Baghena and did not migrate to Tukrur at the time of the Fulani "Exodus," speak Fulanchi at all.

M. Delafosse rejects El Bekri's explanation of the genesis 
of the "Honeihim," 1 because he maintains that Okba, to whose great and famous expedition he assumes allusion is made, never could have advanced so far south.

There is, however, no reason to assume that El Bekri meant Okba, for in both $116 / 734$, and again in $121 / 738$, in the time of the Ummayad Hisham, Obeid Allah, Governor of Africa, sent expeditions into the Western Sudan. "The soldiers," we read, "took what they liked." 2

The Fulani legend, it is true, hangs round Okba, but the allusion must not be pressed, and can be easily explained, without committing the historian El Bekri to an impossible statement.

One of the largest and most heterogeneous tribes in Northern Kordofan is the Kababish-a tribe which according to local tradition was built up on a parent stem who were of the Awlad Okb.'. Who this Okba was precisely is a matter of dispute, and the learned of Kordofan, like Bello in In fak el Maisuri, suggest various Okbas, including Okba bin Yasir, who became Governor of Egypt in 665 A.D.

But, writes Mr. McMichael, "whether their ancestor was governor of Egypt or not, it is practically certain that the Awlad Okba did reside for some time in Northern Africa. All accounts to-day unite in saying that of the Awlad Okba who crossed into Egypt from Arabia a large portion passed through Tripoli, and eventually drifted into the ranks of the Fillata in West Africa; this branch of the Awlad Okba are said to be known nowadays as 'Nas el Sheikh,' 'Omar el Futa,' and 'Nas el Sheikh Othman ibn Fodia' (sic). Others of the tribe are said to have stayed in Egypt and to be known there as the Awlad Ali; while a third portion settled in the Syrian desert near Akaba. This, I think, is quite sufficient to identify the Awlad Okba now in Kordofan as being connected with the Beni Okba whom Dr. Wallin met near Akaba in 1848."

These people informed Dr. Wallin that early in the history of Islam they had been divided into Musalima and Beni Amr,

\footnotetext{
2 i.e., that they were descended from the Unmagad soldiers, who came to Africa in the early days of Islam. Cf. Toumal Asiatigue, Juin, 1859, p. 515.

Ibu cl Athir. Fagaau, p. 60.

- Tribes of Northerm and Central Kordofan, 1912. Camb. Univ. Press.
} 
and that these two sections quarrelled, and that the former expelled the latter from Muweilah, and forced them to join the Hegaja, with whom they still resided near Tafila. "They added that numbers of their tribe had passed over into West Africa, and that others had mixed with the Egyptian Felláhín."

"Dr. Wallin," continues Mr. McMichael, "quotes the author of al'Ibar, who corroborates the author of 'al Mesaliku-1 Absar' in saying that the Beni Okba are bound to secure the road between Egypt and Medina, and adds : 'In Afrikia in the West there are some of them (Beni Okba), as well as in the neighbourhood of Terabolus (Tripoli) ... The Beni Okba may roughly be said to be descendants of Kahtanite (Southern) Arabs, who came north and became fused with the impure Syro-Egyptian Must'arib stock (personified by Isma'il), who in their turn, no doubt, contained a plenteous leaven of Kurds, Copts, Turcomans, Phœnicians, Armenians, \&c., in their ranks. At what time the Beni Okba crossed into Egypt, and how long they have taken to reach their present home (Kordofan), is difficult to say."

A rather significant point brought out by Mr. McMichael is that the Kordofan Beni Okba were not originally a camelowning tribe, for the word Kababish is derived from "kabsh," a ram, which probably means that the tribe were a weak and poor community, unless, of course, it is a "totem" name.

It will be remembered that the most popular and ordinary native accounts of Fulani genealogy bring them from Fezzan -and that they commonly call themselves Beni Okba. Marmol-(cir.) 1520-calls the Awlad Okba a branch of the Beni Hilal, and estimates their military forces at 11,500 . They appear in Leo (I495 A.D.) as "a rude and wilde people and in very deade estranged from al humanitie."

It would appear from these notices that Okba is possibly a late introduction into the Fulani family tree, or else he is to be regarded simply as standing for the leader of "Ummayad soldiers"-an eponymous hero.

The exact details of the formation of the Fulani are past finding out, and do not much matter. The point is that 
all these notices go to show that the Fulani grew into a people out of two factors-one of which was the soldier of heterogeneous type introduced into Africa by the Moslem conquest.

Now if M. Delafosse accepts, as he does, El Bekri's "Famam" or "Honeihim" as Fulani, it is difficult to see why the historians' account of their origin should be doubted. We remember that the early Crusaders, after thirty years' residence in Syria, had become very much assimilated in character "and habits to the people whom they had partly conquered, among whom they lived, and whose daughters they did not disdain to marry. Their children were known as Pullani or Creoles" (Lane Poole, "Suladin," p. 28).

Why should we go out of our way to suggest two different explanations of one word, used at about the same period, by the same people (the Saracens), of two "half-caste" peoples, one in the East and one in the West of their Empire? Surely the known Syrian meaning of the term Fulani is the most probable West African meaning.

And if it be true that "Fulani" are simply "half-castes," does not that explain in itself the fact that it is impossible to define a "Fulani type," and also explain the application of the word "Fulani," by the Hausas in particular (and other natives as well), to "any red or white man" of unknown race?

The Rumawa (Erma), i.e., descendants of the Moorish soldiers who invaded Songhay in about 1600 , are known as "Fulani" - "bastard Fulani," it is said-but still Fulani. The Toronkawa or Toronke are spoken of as the "Fulani Conquerors of the Hausa States," albeit they are not "Fulani" in the strict sense of the term, but Tucolors, i.e., the product of marriages between Fulani and Tukrur negroes. It would seem that the only "pure Fulani" were the children of "Ummayad soldiers" and Berber women. When those children began to intermarry with the blacks, then came the "inferior" or "bastard" Fulani. It is, indeed, quite natural that it should be so, for the rule of the desert and the Sudan on its fringe is "uterine descent."

If, rejecting M. Delafosse's specific Judæo-Syrian migrations, which rest purely on surmise, we accept the Fulani as a 
half-caste people who came into being as the result of the early Moslem expeditions to Ghana, the only points left to decide are :-

(I) To whom are they indebted for their language?

(2) Who were the white or red women who were the first mothers of the Fulani?

Now the distinction between the "rulers" of Ghanan and their subjects drawn by El Bekri obviously applies to the period after the Sanhajetan domination-and it is quite permissible to suppose that previous to 800 A.D. the rulers and ruled in Ghana were fairly homogeneous.

It is, moreover, probable from the continuance of their power for four hundred years that such was the case.

To both the above questions, as the writer has endeavoured to show elsewhere, there is the same answer, viz., to the preexisting Berber populations of the West African littoral, peoples who were found by Hanno on the Wadi Draa (Lixus)" about 500 B.c., who called a pygmy "gorel" 2 gorilla, and who were later known to the Romans as "Canarii," and perhaps as "Leukaithiopes."

H. R. Palmer.

1 Lixus may be simply a Greek transeription of Al Hyksos, which, whatever be its true signification, came to mean "pastors."

- Gor-el is a Fulanchi diminutive $=$ little $\operatorname{man}$ (gor-ko $=\operatorname{man}$ ). 